\title{
Er det slutt på dugnadsånden?
}

Dugnad er et velkjent norsk fenomen: en felles innsats der den enkelte mer eller mindre uegennyttig bidrar til et felles gode. Som forskere har vi ofte opplevd at frivillige begrunner sin deltagelse med at bidraget deres kan komme andre til nytte. Deltagelsen i epidemiologiske studier har imidlertid vært fallende de siste 30-40 årene (1). Dersom dette skyldes synkende dugnadsånd i befolkningen, burde tiltak som øker deltagernes ytre motivasjon - for eksempel belønning i form av gaver eller penger - øke oppslutningen.

I dette nummeret av Tidsskriftet publiserer Gjøstein og medarbeidere resultatene fra en studie av incentiver i en medisinsk spørreundersøkelse om risikofaktorer for tarmkreft (2). De rekrutterte deltagere fra to grupper: én som tidligere ikke hadde svart på en invitasjon til koloskopi, og én som ble tilfeldig trukket fra befolkningen. Disse ble igjen delt i tre undergrupper: skrapelodd vedlagt invitasjonen (ubetinget incentiv), trekning av en iPad dersom de svarte på spørreskjemaet (betinget incentiv), eller ingen incentiver. Blant de 6795 deltagerne var svarprosenten som forventet lavere hos dem som tidligere ikke hadde respondert. Det var imidlertid ingen forskjeller mellom de ulike incentivgruppene.

Betyr dette at vi bør slutte å belønne studiedeltagere? Ikke nødvendigvis. Forskerne valgte et Flax-lodd som ubetinget incentiv. Resultater fra tidligere studier, også i Norge, har vist at pengegaver nok er et bedre valg $(3,4)$. Slik konkluderte også forfatterne av en helt ny studie fra Canada, der det å legge ved to dollar ga en oddsratio for deltagelse på $1,4(95 \% \mathrm{KI} 1,2-1,7)$, mens skrapelodd ikke påvirket svarprosenten (5). Dette er ikke så overraskende: Et skrapelodd vil for de fleste føre til skuffelse - mens de få som vinner, kan bli så oppspilte at de glemmer hele spørreskjemaet.

Utsikter til egen helsegevinst kan også være et incentiv for å delta i helseundersøkelser. Enkelte studier tilbyr kliniske undersøkelser deltagerne ellers ikke ville fått. Det er derfor overraskende at nesten halvparten av de som tidligere ikke hadde respondert på et tilbud om koloskopiscreening, likevel svarte på den aktuelle spørreundersøkelsen. Hos disse kan forventninger om tidsbruk og ubehag knyttet til undersøkelsen ha veiet tyngre enn mulig medisinsk nytte.

Vår erfaring tilsier at problemet med å rekruttere til helseundersøkelser ikke ligger $i$ at folk aktivt avslår, men at mange ikke svarer overhodet. Derfor kan det være fornuftig å bruke ressurser på å forsikre seg om at potensielle deltagere faktisk har mottatt og tatt stilling til henvendelsen. Gjøstein og medarbeidere ringte alle de ikke hadde hørt fra etter to uker, og tilbød dem å svare per telefon. Dette økte deltagelsen med 15 prosentpoeng. Dette er et interessant bifunn. Men de fleste bruker allerede en eller annen form for purring - oftest en ny, skriftlig henvendelse. Kontakt per telefon kan vurderes som utilbørlig press, det er sannsynligvis dyrere enn brev, og det er ikke sikkert at et telefonintervju gir de samme svarene som et spørreskjema returnert i posten. I en dansk undersøkelse fant man at personer som svarte på telefonintervju, oftere brukte mer ekstreme svarkategorier og sjeldnere svaralternativet «vet ikke» (6). Det hadde vært spennende om Gjøstein og medarbeidere gikk videre med sine funn og sammenlignet effekt og kostander av postal purring med telefonhenvendelse.
Manglende effekt av incentiver, og eventuelt forbedret svarprosent ved personlig henvendelse, kan tyde på at det ikke er dalende dugnadsvilje som er problemet. Det er mange andre gode grunner til fallende oppslutning - og muligheter til å bedre den (1): Befolkningen overøses med markedsundersøkelser, på nett, per post og over telefon. Samtidig har omfanget av forskningsprosjekter økt mens tilliten til forskningsresultater antakelig er svekket. Og spørreskjemastudier kan til tider være så omfangsrike og detaljerte at det i seg selv virker avskrekkende. Er studien designet slik at det forutsetter gjentatte forespørsler, bør det dessuten ikke være uventet om frafallet øker etter hvert som tiden går (7).

Kanskje er det en dugnad blant forskerne som må til. Sammen kan vi styrke informasjonen om hvor viktig det er at flest mulig deltar, dersom vi skal få gode mål på befolkningens helse og finne årsaker til vanlige sykdommer. Sammen kan vi også arbeide for færre, bedre og mer poengterte helseundersøkelser, gjennom mer samarbeid og bedre utnyttelse av data.

\section{Ragnhild E. Ørstavik \\ ragnhild.orstavik@tidsskriftet.no \\ Geir Wenberg Jacobsen}

Ragnhild E. Ørstavik (f. 1964) er medisinsk redaktør i Tidsskriftet og seniorforsker ved Folkehelseinstituttet.

Geir Wenberg Jacobsen (f. 1945) er medisinsk redaktør i Tidsskriftet og professor emeritus ved Det medisinske fakultet, Norges teknisk-naturvitenskapelige universitet, Trondheim.

\section{Litteratur}

1. Galea S, Tracy M. Participation rates in epidemiologic studies. Ann Epidemiol 2007; 17: 643-53.

2. Gjøstein DK, Huitfeldt $A$, Løberg $M$ et al. Incentiver og deltagelse i en medisinsk spørreundersøkelse. Tidsskr Nor Legeforen 2016; 136: 1082-7.

3. Edwards PJ, Roberts I, Clarke MJ et al. Methods to increase response to postal and electronic questionnaires. Cochrane Database Syst Rev 2009; 3: MR000008.

4. Finsen V, Storeheier AH. Scratch lottery tickets are a poor incentive to respond to mailed questionnaires. BMC Med Res Methodol 2006; 6: 19

5. Guo Y, Kopec JA, Cibere J et al. Population survey features and response rates: a randomized experiment. Am J Public Health 2016; e1-5.

6. Feveile $H$, Olsen $\mathrm{O}, \mathrm{Hogh} A$. A randomized trial of mailed questionnaires versus telephone interviews: response patterns in a survey. BMC Med Res Methodol 2007; 7: 27.

7. Holmen TL, Bratberg G, Krokstad S et al. Cohort profile of the Young-HUNT Study, Norway: a population-based study of adolescents. Int J Epidemiol 2014; 43: $536-44$.

\section{Engelsk oversettelse på www.tidsskriftet.no}

